\title{
Carcass and Meat Quality of ewe Lambs Supplemented With Crude Glycerin in Different Finishing Systems
}

\section{Qualidade da Carcaça e da Carne de Borregas Suplementadas com Glicerina Bruta em Diferentes Sistemas de Terminação}

Fabíola Cristine de Almeida Rêgo Grecco ${ }^{\text {a }}$ S Simone Fernanda Nedel Pertile; João Marcos Zequim Rodrigues ${ }^{\text {a }}$; Marilice Zundt ${ }^{\mathrm{b}}$; Petrônio Pinheiro Portoc; Luiz Fernando Coelho da Cunha Filho ${ }^{\mathrm{a}}$; Marta Juliane Gasparinia ; Sandra Maria Simonellid; Camila Hernandes de Oliveira ${ }^{\text {a }}$ José Victor Pronievicz Barreto*a

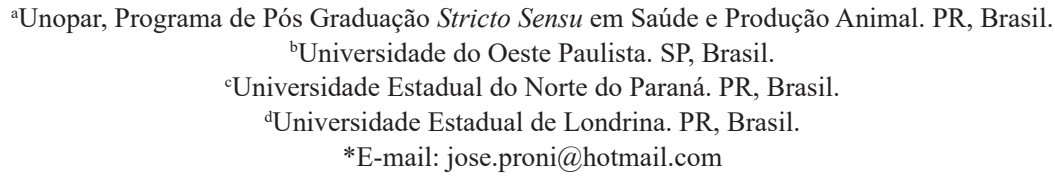

\begin{abstract}
The objective of this study was to evaluate the performance, carcass and meat quality traits of ewe lambs finished in two systems: with their mothers in a creep feeding system and early weaning followed by feedlot. Sixteen Texel $\times$ Hampshire Down crossbred ewe lambs were separated into two treatment groups, consisting of ewe lambs with their mothers, fed by creep feeding or weaned and confined. The diet offered to both treatments consisted of $420 \mathrm{~g} \mathrm{~kg}^{-1}$ of roughage (sugar cane) and $580 \mathrm{~g} \mathrm{~kg}^{-1}$ concentrate, with the addition of $70 \mathrm{~g} \mathrm{~kg}^{-1}$ of crude glycerin in the dry matter of the diet. Blood samples were collected at the beginning and end of the experimental period to measure plasma glucose content. The animals were slaughtered when they reached an average of $28 \mathrm{~kg}$ live weight. Animals finished in creep feeding systems had a higher amount of plasma glucose. The mean values obtained for weight and yield carcass characteristics were better in creep feeding. In general, the chemical composition and meat quality variables did not differ between the finishing systems, except for the $\mathrm{pH}$ value and water loss under pressure. The performance and meat quality traits of ewe lambs in the evaluated finishing systems were similar, and the ewe lambs in the creep feeding system had greater carcass weight than ewe lambs finishing in feedlot systems.
\end{abstract}

Keywords: Byproducts. Carcass Yield. Sheep. Weight Gain.

\section{Resumo}

O objetivo deste estudo foi avaliar as características de desempenho, carcaça e qualidade da carne de borregas terminadas em dois sistemas: com suas mães no sistema de creep feeding e confinadas após o desmame. Dezesseis borregas mestiças Texel x Hampshire Down foram divididas em dois tratamentos: borregas com suas mães, alimentadas em creep feed ou desmamadas e confinadas. A dieta oferecida aos dois tratamentos consistiu em $420 \mathrm{~g} \mathrm{~kg}^{-1}$ de volumoso (cana-de-açúcar) e $580 \mathrm{~g} \mathrm{~kg}^{-1}$ de concentrado, com adição de $70 \mathrm{~g} \mathrm{kg-1}$ de glicerina bruta na matéria seca da dieta. Amostras de sangue foram coletadas no início e no final do periodo experimental para avaliar a glicemia. Os animais foram abatidos quando atingiram peso vivo médio de $28 \mathrm{~kg}$. Os animais terminados no sistema creep feeding apresentaram maior nivel de glicose plasmática. Os valores médios obtidos para as características de peso e rendimento de carcaça foram maiores para os animais criados no sistema creep feeding. Em geral, as variáveis de composição química e características da carne dos animais não diferiram entre os sistemas de terminação, exceto o valor do pH e a capacidade de retenção de água. As características de desempenho e qualidade da carne de borregas terminadas nos sistemas avaliados foram semelhantes, e as borregas terminadas no sistema creep feeding tiveram carcaças mais pesadas do que as terminadas nos sistemas de confinamento.

Palavras-chave: Ganho de peso. Ovinos. Rendimento de carcaça. Subproduto.

\section{Introduction}

Lambs finishing in feedlot is a practice used by sheep producers to improve the young animals' performance and avoid losses caused by nutritional deficiencies and parasitic infestations. This finishing system contributes to a reduction in animals' slaughter age, increase in meat supply during the year, and return on investment in the short term (MEDEIROS et al., 2009).

Among the management tools used for finishing lambs, two methods in particular stand out: one in which the lambs are raised with their mothers in the creep feeding system until they reach slaughter weight, and the other with "early weaning", which occurs approximately at two months of age. Studies have demonstrated that lambs weaned early and finished on pasture exhibit weight and body condition scores at slaughter lower than lambs not weaned or supplemented with concentrate or roughage with adequate nutritional quality (FERNANDES et al., 2011).

However, the ideal tools for management will change according to the region and food quality available for the animals, among other factors. Nutrition has an important effect on the carcass and meat composition and, consequently, animals with better diets have carcasses with better quality. In addition, the different production systems also affect the animals' performance and metabolic profile (FERNANDES et al., 2010).

Owing to the high costs of animal feeding, there is a tendency to use byproducts to replace noble foods. This replacement, 
however, should not affect the intake and animal performance (LAGE et al., 2010). Furthermore, one of the byproducts used for feeding ruminants is crude glycerin, derived from biodiesel production. Crude glycerin has the potential to partially replace starch-based plant ingredients such as corn grains. Once glycerol (composition of $85 \%$ dry matter of crude glycerin) is converted into propionate in the rumen, it acts as a precursor to hepatic glucose synthesis (GUNN et al., 2010).

The objective of this study was to evaluate the performance, carcass and meat quality traits of ewe lambs finishing in two systems: with their mothers in a creep feeding system and early weaning followed by feedlot.

\section{Material and Methods}

The experiment was carried out on a farm in the city of

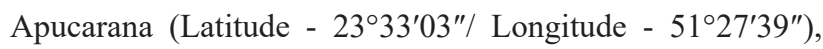
Paraná, Brazil. The experimental procedures were approved by the Ethics Committee on Animal Use of UNOPAR (CEUA 013/13).

Sixteen Texel $\times$ Hampshire Down crossbred ewe lambs were used, all approximately 60 days old with a mean weight of $13.75 \pm 3.84 \mathrm{~kg}$. The ewe lambs were distributed in two treatments, the creep feeding system and the feedlot system. For the creep feeding system, mothers stayed at pasture during the day, and at night they were confined with the ewe lambs. For the feedlot system, the ewe lambs were weaned immediately before the experiment and confined. Before the beginning of the experiment, the animals received two doses of vermifuge (Levamisol, $1 \mathrm{~mL}$ per $50 \mathrm{~kg}$ ).

The same diet (Table 1) was offered for both treatments and was formulated according to the nutritional requirements outlined by the NRC (2007). The diet was composed of 420 $\mathrm{g} \mathrm{kg}^{-1}$ roughage (sugar cane) and $580 \mathrm{~g} \mathrm{~kg}^{-1}$ concentrate food on dry matter (DM), with the addition of $70 \mathrm{~g} \mathrm{~kg}^{-1}$ of crude glycerin in DM as an alternative source of energy. The diet was provided twice a day, at 8h:00 a.m and 04h:00 p.m. The food offered considered that $15 \%$ of the leftovers remained in the feeding trough per day. Food intake was measured daily. The considered adaptation period was one week.

Table 1 - Chemical-bromatological composition of the total diet (roughage, concentrate and crude glycerin) of ewe lambs in different finishing systems

\begin{tabular}{|c|c|c|c|}
\hline Ingredients & \multicolumn{3}{|c|}{$\mathrm{g} \mathrm{kg}^{-1}$ of DM } \\
\hline Sugar cane & \multicolumn{3}{|c|}{420} \\
\hline Corn ground & \multicolumn{3}{|c|}{290} \\
\hline Soybean meal & \multicolumn{3}{|c|}{180} \\
\hline Mineral salt & \multicolumn{3}{|c|}{23} \\
\hline Limestone & \multicolumn{3}{|c|}{13} \\
\hline Common salt & \multicolumn{3}{|c|}{4} \\
\hline Crude glycerin & \multicolumn{3}{|c|}{70} \\
\hline \multirow{2}{*}{$\begin{array}{l}\text { Chemical } \\
\text { Composition } \\
\text { of Diet }\end{array}$} & & \multicolumn{2}{|c|}{ Treatments } \\
\hline & $\begin{array}{c}\text { Sugar Cane in } \\
\text { natura }\end{array}$ & $\begin{array}{c}\text { Creep } \\
\text { Feeding }\end{array}$ & Feedlot \\
\hline DM $\left(\mathrm{g} \mathrm{kg}^{-1}\right)$ & 270.7 & 645 & 646 \\
\hline
\end{tabular}

\begin{tabular}{|l|c|c|c|}
\hline $\mathrm{MM}\left(\mathrm{g} \mathrm{kg}^{-1}\right)$ & 43.1 & 71.6 & 82.1 \\
\hline $\mathrm{CP}\left(\mathrm{g} \mathrm{kg}^{-1}\right)$ & 26.2 & 125.3 & 120.5 \\
\hline $\mathrm{EE}\left(\mathrm{g} \mathrm{kg}^{-1}\right)$ & 4.3 & 14.3 & 10.5 \\
\hline $\mathrm{NDF}\left(\mathrm{g} \mathrm{kg}^{-1}\right)$ & 474.5 & 261.1 & 256.1 \\
\hline ADF $\left(\mathrm{g} \mathrm{kg}^{-1}\right)$ & 271.7 & 137.7 & 132 \\
\hline Lignin $\left(\mathrm{g} \mathrm{kg}^{-1}\right)$ & 35.1 & 19.7 & 16.8 \\
\hline NIDN $\left(\mathrm{g} \mathrm{kg}^{-1}\right)$ & 2.0 & 11.2 & 6.6 \\
\hline ADIN $\left(\mathrm{g} \mathrm{kg}^{-1}\right)$ & 1.4 & 3.3 & 4.2 \\
\hline TDN $\left(\mathrm{g} \mathrm{kg}^{-1}\right)$ & 636.0 & 810.0 & 800.0 \\
\hline
\end{tabular}

$\mathrm{DM}=$ dry matter; $\mathrm{MM}=$ mineral matter; $\mathrm{CP}=$ Crude protein; $\mathrm{EE}=$ ethereal extract; $\mathrm{NDF}=$ neutral detergent fiber; $\mathrm{ADF}=$ acid detergent fiber; NIDN = insoluble nitrogen in neutral detergent; NIDA = insoluble nitrogen in acid detergent; TDN $=$ total digestible nutrients.

Source: Research data.

Representative samples were collected from sugarcane in natura and from the total diet offered into the trough (concentrate, roughage, and crude glycerin) for qualitative analyzes, which were performed at the Bromatology Laboratory (campus Arapongas - UNOPAR).

The samples were pre-dried under forced air circulation at $55^{\circ} \mathrm{C}$ for 72 hours to ensure the matter partially dried, then they were processed in a Wiley mill with a 1-mmsieve and stored for later analysis. The content levels of dry matter (DM), mineral matter (MM), organic matter (OM), crude protein (CP), ether extract (EE), neutral detergent fiber (NDF), acid detergent fiber (ADF), lignin, cellulose, neutral detergent insoluble nitrogen (NIDN) and acid detergent insoluble nitrogen (ADIN) in the samples were obtained according to methodology described by Mizubuti et al. (2009).

The content levels of total carbohydrates (TC) and nonfibrous carbohydrates (NFC) were estimated according to Sniffen et al. (1992), considering that TC $=100 *(\% \mathrm{CP}+$ $\% \mathrm{EE}+\% \mathrm{MM})$ and that $\mathrm{NFC}=100-(\% \mathrm{NDF} p+\% \mathrm{CP}+$ $\% \mathrm{EE}+\% \mathrm{ash}$ ), in which NDFcp is equivalent to cell wall corrected for ashes and protein.

To estimate the values of total digestible nutrients (TDN) (Table 1), the following formula was used (NRC, 2001): TDN $=\mathrm{NFCd}+\mathrm{CPd}+(\mathrm{FAd} \times 2.25)+\mathrm{NDFd}-7$, where $\mathrm{NFCd}$ equals digestible non-fibrous carbohydrates, $\mathrm{CPd}$ corresponds to digestible crude protein, FAd represents digestible fatty acids, and NDFnd corresponds to NDF corrected for digestible nitrogen.

The animals' weights were obtained at the beginning of the adaptation period and every 15 days during the experiment, always before the first food supply of the day, and total weight gain and average daily weight gain were obtained. On the last day of the experiment, the animals were fasted from solid diet for 16 hours. The ewe lambs were slaughtered when they reached the average live weight of $28 \mathrm{~kg}$, which occurred after 80 days of feedlot.

To determine the glucose content, blood samples were collected prior to slaughter via puncture of the jugular vein, using Vacutainer tubes with heparin $(7 \mathrm{~mL})$. The blood samples were centrifuged (2.500 rpm for 15 minutes), and then 
the plasma was removed and stored in $1 \mathrm{~mL}$ Eppendorf tubes. The plasma glucose level was determined using a BioPlus spectrophotometer with Analisa Gold commercial kits at the Center of Diagnosis of Veterinary Medicine (Campus Arapongas - UNOPAR).

The live weight at slaughter (BW) was obtained and the animals were subsequently stunned by pneumatic gun and slaughtered by sectioning the jugular vein and carotid artery. Then, the gastrointestinal tract and its contents were removed from each animal to obtain the empty body weight (EBW), which is the difference between the live weight at slaughter and the weight of the gastrointestinal content (SAÑUDO; SIERRA, 1986).

After evisceration, the hot carcass weight was obtained (HCW), and then the carcasses were transferred to a cold chamber at $4{ }^{\circ} \mathrm{C}$, where they remained for 24 hours. At the end of this period, the carcasses were weighed to obtain the cold carcass weight (CCW). From the live weight at slaughter, the hot carcass weight, and the cold carcass weight, the hot carcass yield $\left(\mathrm{HCY}=\mathrm{HCY} / \mathrm{BW}^{*} 100\right)$, cold carcass yield $(\mathrm{CCY}=$ $\left.\mathrm{CCW} / \mathrm{BW}^{*} 100\right)$, and the variable losses by cooling (LBC $=$ $\left.\left(\mathrm{HCW}^{*} \mathrm{CCW} / \mathrm{BW}\right)^{*} 100\right)$ were calculated, as described by Osório and Osório (2005). The biological carcass yield (BCY) was obtained using the equation $\mathrm{BCY}=(\mathrm{HCW} / \mathrm{EBW}) \times 100$ (SAÑUDO; SIERRA, 1986).

The conformation was obtained considering values from 1 to 5 ( $1=$ concave and $5=$ convex $)$. For the subcutaneous fat cover evaluation (SFC), scores were also considered between 1 and $5(1=$ absent fat cover and $5=$ abundant fat cover $)$. Both characteristics were evaluated using photographic standards (CAÑEQUE; SAÑUDO, 2000).

The characteristics of meat quality were measured at the longissimus dorsi muscle, 24 hours post-mortem. The meat color measurements were performed using a colorimeter (Konica Minolta $\AA$ ) for luminosity evaluation $\left(\mathrm{L}^{*} 0=\right.$ Black, $100=$ white), intensity of the red-green color $\left(a^{*}\right)$, and intensity of the yellow-blue color ( $\left.b^{*}\right)$, as described by Houben, Dijk, Eikelenboom, and Hoving-Bolink (2000). Marbling (MARB) was evaluated subjectively using photographic standards, where marks were assigned on a scale from 1 to $6(1=$ traces of marbling and $6=$ abundant marbling) (AMSA, 2001).

The meat $\mathrm{pH}$ measurement was performed in the longissimus dorsi muscle 24 hours post-mortem, with the aid of a portable digital potentiometer, in accordance with the study carried out by Bressan et al. (2001). The water loss under pressure (LWP) was obtained via the method of pressure application, using a circular object of $10 \mathrm{~kg}$ and a meat sample protected by filter paper (CAÑEQUE; SAÑUDO, 2000).

Samples of each animal were frozen for the material preservation. After this, the samples were thawed under refrigeration $\left(5^{\circ} \mathrm{C}\right)$ for 24 hours, and the thawing loss was determined as the ratio between the weight of the defrosted sample and the weight of the frozen sample, multiplied by 100. The cooking loss was determined according to Wheeler,
Shackeford and Koohmaraie (1996). Samples were initially weighed and then roasted in a gas oven, pre-heated to a temperature of $170^{\circ} \mathrm{C}$, until the samples reached $71^{\circ} \mathrm{C}$ in their geometric center, as measured by a digital thermometer. After cooking, the samples were cooled to room temperature and weighed again. The cooking loss was calculated as the difference between the initial and final weight of the sample, expressed as a percentage of the initial weight.

A sample of the muscle tissue of each animal was collected on the longissimus dorsi and the amount of moisture, protein, ethereal extract, and ashes in each sample was determined. During the samples preparation, visible fat was removed and the samples were then homogenized in a multi-processor. These analyzes were carried out in accordance with guidelines from the Association of Official Analytical Chemists (AOAC, 2005).

The experimental design was completely randomized, with two treatments consisting of eight replicates per treatment. Statistical analyzes were performed by the GLIMMIX procedure of software SAS ${ }^{\circledR}$ University Edition (SAS Institute Inc., Cary, North Carolina). The assumptions of variance analysis, including normality of residues and the homogeneity of variance, were verified using the Shapiro Wilk test and the chi square test, respectively. For weight gain and BW, the covariate initial weight was considered, which was significant only for the weight at slaughter. For the variables $\mathrm{HCW}, \mathrm{CCW}$, $\mathrm{HCY}, \mathrm{CCY}$ and BCY, the slaughter weight was considered as a covariate, and for carcass quality traits, the cold carcass weight was considered as a covariate. The difference between treatments was assessed by $\mathrm{F}$ test. A significance level of 5\% of probability was considered.

\section{Results and Discussion}

The average consumption of dry matter (DM) by the ewe lambs was $585.34 \mathrm{~g} \mathrm{~d}^{-1}$ and $581.0 \mathrm{~g} \mathrm{~d}^{-1}$ for creep feeding and feed lot systems, respectively, corresponding to $2.79 \%$ and $2.76 \%$ of live weight. According to the NRC (2007), the DM intake of animals with live weight between 20 and $30 \mathrm{~kg}$ should be between 1.0 to $1.3 \mathrm{~kg}$ of DM per day, and thus the average consumption obtained in this study was lower than the recommended one. The low DM intake in both treatments may be related to the use of sugar cane as roughage in the diet. The fiber from sugar cane has a low degradation rate in the rumen, resulting in accumulation of non-degraded fiber, and consequently limitation of consumption due to ruminal fullness (FREITAS et al., 2006).

The averages of daily weight gain were $179 \mathrm{~g} \mathrm{~d}^{-1}$ and 178 $\mathrm{g} \mathrm{d}^{-1}$ for the animals in creep feeding and feedlot, respectively, and these values are below the $250 \mathrm{~g} \mathrm{~d}^{-1}$ indicated by the NRC (2007) for animals with weights similar to those obtained in the present study. Moreover, live weight at slaughter, total weight gain, average daily weight gain were similar for both finishing systems compared in this study; the mother's presence did not influence the ewe lambs' weight gain, and this result may be related to the decline in milk production that 
happens after the fourth week of lactation.

Regarding the glucose content of the ewe lambs' blood, the obtained values remained within the standards of normality (50 - $80 \mathrm{mg} \mathrm{dL}^{-1}$ ) recommended by Kaneko, Harvey and Bruss (2008). However, there was significant difference between the two studied treatments, and the highest value was obtained for the ewe lambs in creep feeding system $\left(65.63 \mathrm{mg} \mathrm{dL}^{-1}\right.$ for creep feeding versus $50.94 \mathrm{mg} \mathrm{dL}^{-1}$ for feedlot). These results may be related to the occurrence of breastfeeding in the creep feeding system. During the breastfeeding period, the main source of the animal's glucose is lactose, while in pre-ruminant animals an increase occurs in production and absorption of propionate, which is a glucose precursor. This increase leads to a greater glucose synthesis in the liver, and consequently greater availability of glucose to peripheral tissues (KOZLOSKI, 2009). Thus, in animals maintained in the creep feeding system during the pre-ruminant phase, an increase in blood glucose content is expected.

For the variables HCW, CCW, HCY, CCY and BCY (Table 2), significant differences were obtained between the two treatments, and the best performances were achieved in the creep feeding system. Rego et al. (2015) compared the levels of crude glycerin inclusion in the diet of Texel crossbred lambs in feedlot, using $0 \%, 7 \%, 14 \%$, and $21 \%$ of glycerin in substitution of corn, and the values obtained for $\mathrm{HCW}$, $\mathrm{CCW}, \mathrm{HCY}, \mathrm{CCY}$ and BCY in ewe lambs supplemented with $70 \mathrm{~g} \mathrm{~kg}^{-1}$ of crude glycerin were $17.22 \%, 16.69 \%, 44.72 \mathrm{~kg}$, $43.32 \mathrm{~kg}$ and $49.77 \mathrm{~kg}$, respectively. The results in this study for these traits were lower than those reported by Rego et al. (2015), which could be related to the animals' gender and the greater acceptance and digestion of corn silage used by these authors in relation to the sugar cane.

Table 2 - Averages and standard deviations for performance, carcass traits and plasma glucose content of ewe lambs in different finishing systems

\begin{tabular}{|l|c|c|}
\hline \multirow{2}{*}{\multicolumn{1}{|c|}{ Variables }} & \multicolumn{2}{c|}{ Treatments } \\
\cline { 2 - 3 } & Creep feeding & Feedlot \\
\hline Initial weight $(\mathrm{kg})$ & $13.37 \mathrm{a} \pm 3.739$ & $14.13 \mathrm{a} \pm 4.156$ \\
\hline BW $(\mathrm{kg})$ & $27.69 \mathrm{a} \pm 5.898$ & $28.37 \mathrm{a} \pm 5.236$ \\
\hline TWG $(\mathrm{kg})$ & $14.31 \mathrm{a} \pm 2.259$ & $14.25 \mathrm{a} \pm 2.109$ \\
\hline ADG $(\mathrm{Kg} /$ day) & $0.179 \mathrm{a} \pm 0.036$ & $0.178 \mathrm{a} \pm 0.028$ \\
\hline Glucose (mg/dl) & $65.63 \mathrm{a} \pm 8.383$ & $50.94 \mathrm{~b} \pm 6.673$ \\
\hline HCW $(\mathrm{kg})$ & $12.09 \mathrm{a} \pm 2.941$ & $11.03 \mathrm{~b} \pm 2.449$ \\
\hline CCW $(\mathrm{kg})$ & $11.82 \mathrm{a} \pm 2.869$ & $10.79 \mathrm{~b} \pm 2.394$ \\
\hline HCY $(\%)$ & $43.55 \mathrm{a} \pm 3.032$ & $39.68 \mathrm{~b} \pm 2.018$ \\
\hline CCY $(\%)$ & $42.58 \mathrm{a} \pm 2.955$ & $38.81 \mathrm{~b} \pm 2.000$ \\
\hline BY $(\%)$ & $49.84 \mathrm{a} \pm 2.161$ & $47.17 \mathrm{~b} \pm 2.077$ \\
\hline LBC $(\%)$ & $2.30 \mathrm{a} \pm 0.278$ & $2.17 \mathrm{a} \pm 0.296$ \\
\hline Conformation $(1-5)$ & $3.34 \mathrm{a} \pm 1.414$ & $2.91 \mathrm{a} \pm 1.165$ \\
\hline SFC (1-5) & $1.95 \mathrm{a} \pm 0.535$ & $1.92 \mathrm{a} \pm 0.354$ \\
\hline
\end{tabular}

Means within a line with different superscripts are significantly different $(\mathrm{P}<0.05) . \mathrm{BW}=$ live weight at slaughter; $\mathrm{TWG}=$ total weight gain; $\mathrm{ADG}$ = average daily weight gain; $\mathrm{HCW}=$ hot carcass weight; $\mathrm{CCW}=$ cold carcass weight HCY $=$ hot carcass yield CCY $=$ cold carcass yield; $\mathrm{BY}=$ biological yield; $\mathrm{LBC}=$ losses by cooling; $\mathrm{SFC}=$ Subcutaneous fat cover. Source: Research data.
The animal's conformation is a measure that shows the most valuable cuts of carcass. A great proportion for each cut is the one in which the cut reaches maximum appreciation in value for both the producer and the consumer. Therefore, as there is a difference in economic values between each cut, the proportion of each one is important to evaluate the carcass commercial quality (RODRIGUES et al., 2008). Thus, no significant differences were obtained in variable conformation, and both finishing systems assessed have the same commercial importance in relation to cuts of meat.

SFC is a subjective measure obtained in accordance with the fat distribution in the animal carcass. The values obtained of conformation and SFC in the present study were higher than those found by Rego et al. (2015), who obtained the values 3.14 and 2.42, respectively, for these variables in lambs that received $70 \mathrm{~g} \mathrm{~kg}^{-1}$ of crude glycerin in their diet. Thus, the use of this byproduct does not negatively affect the animal's carcass.

In general, the meat quality variables did not differ between the finishing systems, except for the $\mathrm{pH}$ value and LWP. The average values of muscle $\mathrm{pH}$ obtained in ewe lambs in the creep feeding and feedlot systems were 4.74 and 5.57, respectively. The final meat $\mathrm{pH}$ value is related with possible pre-slaughter stress based on the lactic acid accumulation, which acts as a precursor to the muscular glycogen and is more pronounced in the first post-mortem hours (BONACINA et al., 2011). However, the animal's pre-slaughter management was the same for both treatments, and nothing occurred which characterized a pre-slaughter stress.

The average values for meat color $\left(\mathrm{L}, \mathrm{a}^{*}\right.$, and $\left.\mathrm{b}^{*}\right)$ in the present study were lower than those obtained by Rego et al. (2017) $(42.88,12.84$, and 8.82 for L, a*, and b*, respectively) for feedlot lambs supplemented with a level of $70 \mathrm{~g} \mathrm{~kg}^{-1}$ of crude glycerin. The same authors obtained an average value of $\mathrm{pH}$ of 5.58 for feedlot animals, which was similar to those obtained in the present study. The values for thawing loss and cooking loss were similar between the treatments, with mean values of $8.19 \%$ and $53.48 \%$, respectively. However, for LWP, lower values were obtained in ewe lambs finishing in feedlot systems.

The meat chemical composition was shown in Table 3, and the variables did not show differences between the treatments $(\mathrm{p}>0.05)$.

Table 3 - Averages and standard deviations for meat quality traits of ewe lambs in different finishing systems

\begin{tabular}{|l|c|c|}
\hline \multirow{2}{*}{\multicolumn{1}{|c|}{ Variables }} & \multicolumn{2}{c|}{ Treatments } \\
\cline { 2 - 3 } & Creep Feeding & Feedlot \\
\hline $\mathrm{L}$ & $38.60 \mathrm{a} \pm 4.300$ & $40.20 \mathrm{a} \pm 3.250$ \\
\hline $\mathrm{a}^{*}$ & $16.89 \mathrm{a} \pm 1.619$ & $16.16 \mathrm{a} \pm 1.189$ \\
\hline $\mathrm{b}^{*}$ & $7.89 \mathrm{a} \pm 0.768$ & $7.40 \mathrm{a} \pm 0.991$ \\
\hline $\mathrm{pH}$ & $4.74 \mathrm{~b} \pm 0.049$ & $5.57 \mathrm{a} \pm 0.084$ \\
\hline MARB (1-6) & $2.38 \mathrm{a} \pm 0.744$ & $1.88 \mathrm{a} \pm 0.641$ \\
\hline LWP $(\%)$ & $29.52 \mathrm{a} \pm 3,523$ & $23.32 \mathrm{~b} \pm 2,14$ \\
\hline LWT $(\%)$ & $8.53 \mathrm{a} \pm 1.623$ & $7.85 \mathrm{a} \pm 1.370$ \\
\hline
\end{tabular}




\begin{tabular}{|l|c|c|}
\hline LWC (\%) & $52.63 \mathrm{a} \pm 3.566$ & $54.33 \mathrm{a} \pm 4.493$ \\
\hline Moisture (\%) & $74.2 \mathrm{a} \pm 0.917$ & $74.62 \mathrm{a} \pm 0.700$ \\
\hline Protein (\%) & $21.43 \mathrm{a} \pm 1.458$ & $20.99 \mathrm{a} \pm 1.873$ \\
\hline $\begin{array}{l}\text { Ethereal extract } \\
(\%)\end{array}$ & $4.5 \mathrm{a} \pm 0.495$ & $4.12 \mathrm{a} \pm 0.840$ \\
\hline Ash (\%) & $1.13 \mathrm{a} \pm 0.117$ & $1.13 \mathrm{a} \pm 0.074$ \\
\hline
\end{tabular}

Means within a line with different superscripts are significantly different $(\mathrm{P}<0.05)$. L = luminosity; $\mathrm{a}^{*}=$ red-green color intensity; $\mathrm{b}^{*}=$ yellow-blue color intensity; MARB = marbling; LWP = loss of water by pressure; LWT $=$ thawing loss; LWC $=$ cooking loss.

Source: Research data.

\section{Conclusion}

The performance and meat quality traits of ewe lambs were similar in the evaluated finishing systems. However, ewe lambs in finishing systems with the presence of their mothers showed carcasses with greater weight and yield, which can increase the production system profitability.

\section{References}

AMSA - American Meat Science Association. Handbook meat evaluation of American Meat Science Association. Champaign: AMSA, 2001.

AOAC - Association of Official Analytical Chemists. Official methods of analysis of the Association of Analytical Chemists International Gaithersburg: AOAC International, 2005.

BONACINA, M.S. et al. The influence of sex and finishing system on carcass and meat quality of Texel $\times$ Corriedale lambs. Rev. Bras. Zootec., v.40, n.6, p.1242-1249, 2011. doi: 10.1590/ S1516-35982011000600012

BRESSAN, M.C. et al. Effect of the slaughter weight on the physical-chemical characteristic of Bergamácia and Santa Inês lambs meat. Ciênc. Tecnol. Aliment., v.21, n.3, p.293-303, 2001. doi: 10.1590/S0101-20612001000300008

CAÑEQUE, V.; SAÑUDO, C. Metodologia para el estúdio de la calidad de la canal y de la carne em ruminantes. Madrid: INIA, 2000.

FERNANDES, M.A.M. et al. Tissue composition of carcass and meat fatty acids profile of lambs finished on pasture and feedlot systems. Rev. Bras. Zootec., v.39, n.7, p.1600-1609, 2010. doi: 10.1590/S1516-35982010000700029

FERNANDES, S.R. et al. Early weaning and concentrate supplementation on slaughter weight and carcass characteristics of lambs produced on pasture. Rev. Bras. Saúde Prod. Anim., v.12, n.2, p.527-537, 2011.

GUNN, P.J. et al. Effects of crude glycerin on performance and carcass characteristics of finishing wether lambs. J. Anim. Sci., v.88, n.5, p.1771-1776, 2010. doi: 10.2527/jas.2009-2325

FREIRE, A.M.T. et al. Determinação de parâmetros físicoquímicos e de aceitação sensorial da carne de cordeiros proveniente de diferentes tipos raciais. Alim. Nutr., v.21, n.3, p.481-486, 2010 .

FREITAS, A.W.P. et al. Evaluation of the nutritional divergence of sugarcane (Saccharum spp.) genotypes. Rev. Bras. Zootec., v.35, n.1, p.229-236, 2006. doi: 10.1590/S1516-35982006000100029

HOUBEN, J.H. et al. Effect of dietary vitamin E supplementation, fat level and packaging on color stability and lipid oxidation in minced meat. Meat Sci., v.55, n.3, p.331-336, 2000. doi: 10.1016/ S0309-1740(99)00161-8

KANEKO, J.J.; HARVEY, I.W.; BRUSS, M.L. Clinical biochemistry of domestic animals. Davis: Academic, 2008.

KOZLOSKI, G.V. Bioquímica dos ruminantes. Santa Maria: UFSM, 2009.

LAGE, J.F. et al. Crude glycerin on finishing lamb diets. Pesq. Agropec. Bras., v.45, n.9, p.1012-1020, 2010. doi: 10.1590/ S0100-204X2010000900011

MEDEIROS, G.R. et al. Effect of concentrate levels on carcass characteristics of the Morada Nova breed sheep in feedlot. Rev. Bras. Zootec., v.38, n.4, p.178-727, 2009. doi: 10.1590/S151635982009000400019

MIZUBUTI, I.Y. et al. Métodos laboratoriais de avaliação de alimentos para animais. Londrina, PR: EDUEL, 2009.

NRC - National Research Council. Nutrient requirements of dairy cattle. Washington: Natl. Acad. 2001.

NRC - National Research Council. Nutrient requirements of small ruminants: Sheep, goats, cervids, and new world camelids. Washington: Natl. Acad. Press, 2007.

OSÓRIO, J.C.S.; OSÓRIO, M.T.M. Produção de carne ovina: técnicas de avaliação "in vivo" e na carcaça. Pelotas, RS: UFPEL, 2005.

REGO, F.C.A. et al. Development, economic viability and attributes of lamb carcass from confined animals fed on different amounts of crude glycerin. Sem. Cienc. Agrá., v.36, n.5, p.34453454, 2015. doi: 10.5433/1679-0359.2015v36n5p3445

REGO, F.C.A. et al. Fatty acid profile and lambs' meat quality fed with different levels of crude glycerin replacing corn. Sem. Cienc. Agrá., v.38, n.4, p.2051-2064, 2017. doi: 10.5433/1679-0359.2017v38n4p2051

RODRIGUES, G.H. et al. Citrus pulp in diets for feedlot lambs: carcass characteristics and meat quality. Rev. Bras. Zootec., v.37, n.10, p.1869-1875, 2008. doi: 10.1590/S151635982008001000022

SAÑUDO, C.; SIERRA, I. Calidad de la canal en la espécie ovina. Ovino, v.1, p.127-157, 1986.

SNIFFEN, C.J. et al. A net carbohydrate and protein system for evaluating cattle diets: II. Carbohydrate and protein availability. J. Anim. Sci., v.70, n.11, p.3562-3577, 1992. doi: 10.2527/1992.70113562x

WHEELER, T.I.; SHACKEFORD, S.D.; KOOHMARAIE, M. Sampling, cooking and coring effects on Warner-Bratzler shear force values in beef. J. Anim. Sci., v.74, n.7, p.1553-1562, 1996. doi: $10.2527 / 1996.7471553$. 